\title{
In vitro Inhibitory Effect of Aged Black Garlic Extract with Antioxidant Activity on MMP-2 and MMP-9 Related to Metastasis
}

\author{
Soo-Jin Lee', Hyang-Nam¹, Moon-Moo Kim¹, Ho-Jung Jang², Jung Ae Park², Byung-Woo Kim³ \\ and Kyung Tae Chung ${ }^{3,4}$ \\ ${ }^{1}$ Department of Chemistry, ${ }^{2}$ Department of Life Science and Biotechnology, ${ }^{3}$ Blue-Bio Industry RIC, ${ }^{4}$ Department of Clinical Laboratory Science, \\ Dong-Eui University, Busan, 614-714, Korea
}

Received April 6, 2010 /Accepted April 16, 2010

\begin{abstract}
The oxidative damage of lipids, protein, and DNA is known to be involved in not only chronic inflammations such as arthritis, hepatitis, nephritis, gastritis, colitis, and periodontitis but also metastasis. It has given impetus to searching for natural compounds without toxicity, which prevent the development of these diseases. The direct scavenging effects of aged black garlic extract (ABGE) were evaluated in vitro on DPPH radical, hydroxyl radical, hydrogen peroxide, and genomic DNA damage related to oxidative stress. Furthermore, its antioxidant effect on lipid peroxidation was investigated in human fibrosarcoma cells (HT1080), which were exposed to the hydroxyl radical generated by the Fenton reaction. It was observed that ABGE exhibited a greater inhibitory effect on hydrogen peroxide than other reactive oxygen species, and also blocked DNA oxidation and lipid peroxidation induced by the hydroxyl radical. The oxidative stress in live cells was also inhibited in the presence of ABGE. In addition, its inhibitory effects on the activity and expression of MMP-2 and -9 related to metastasis were determined using gelatin zymography and western blot. The data showed that it inhibited MMP-2 and -9 in PMA-stimulated HT1080 cells. Therefore, these results suggest that ABGE show potential as an excellent agent for prevention of metastasis related to oxidative stress.
\end{abstract}

Key words : Aged black garlic, antioxidant, hydroxyl radical, MMPs

\section{서 론}

최근 전통한약 및 천연물로부터 기능성식품의 개발을 위하 여 항산화, 고혈압, 당뇨병, 비만, 면역활성강화, 암예방 및 항 노화에 효능이 있는 생리활성 물질에 대한 연구가 집중되고 있다. 특히 산화적 스트레스에 의하여 발생되는 활성산소는 생체 내에서 지질과산화를 비롯하여 단백질, 탄수화물 및 DNA 산화에 의한 혈관순환계 질환, 암발생 및 피부노화 등 다양한 질환의 발생에 관련이 있는 것으로 보고되고 있어, 대 체의학분야에서 항산화제가 중요한 기능성 바이오 소재로 각 광 받고 있다[3,21,23,25,26]. 전통적으로 안전성이 확보되어 있 는 항산화제로는 vitamin C 및 $\mathrm{E}$ 를 비롯하여 약용식물 등에 함유되어 있는 폴리페놀화합물로curcumin, resveratrol, eugenol, propolis 등이 알려져 있다 $[6,11,13,16,18,22]$. 특히, 황을 함유하고 있는 유기 황화합물을 많이 함유하는 마늘은 예로부 터 다양한 약리적 작용으로 민간에서 널리 사용 되어져 왔다. 마늘은 활성산소를 제거하고[12], 지질과산화물 형성과 LDL (low density lipoprotein) 산화를 억제하는 항산화 효능이 있 는 것으로 보고 되고 있다[1]. 또한, 마늘은 운동에 의한 산화스 트레스를 감소시켜 뚜렷한 혈중지질 저하 효과와 더불어 항산

*Corresponding author

Tel : +82-51-890-2681, Fax : +82-51-890-2622

E-mail : kchung@deu.ac.kr
화 효소의 발현을 증가시켜 지질과산화물의 형성을 억제함으 로서 산화스트레스를 감소시키는 효능이 있는 것으로 보고되 고 있다[28]. 더욱이 마늘의 이러한 생리활성물질의 특성은 유 기황화 물질의 유도체에 기인한다고 보고되고 있다. 예를 들 면, 중금속 중독의 해독작용, 혈중 지질농도 저하효과, 혈소판 응집 억제 및 혈관수축 억제 기능 등 다양한 기능이 보고되고 있다. 그러나 마늘의 부작용으로 기관지 수축, 구토, 설사, 저 혈당 및 접촉피부염 등의 부작용을 일으킬 수도 있다는 것이 보고되고 있다[7]. 뿐만 아니라 마늘의 자극적인 냄새와 맛으 로 인하여 다양한 생리활성을 나타내기에 충분한 양을 지속적 으로 섭취 하기는 어렵다. 따라서 마늘의 자극적인 냄새와 향 을 감소시키는 방법인 열처리를 하게 되면 단백질, 지질 및 당질에 의하여 자극적인 냄새가 감소되는 것으로 보고되고 있다[29]. 그러므로 마늘은 유효성분을 활용한 건강기능성식 품 개발의 매우 좋은 소재이나 자극적인 향기로 인하여 가공 식품의 개발에는 다소 어려움이 따르고 있는 실정이다. 최근, 마늘의 자극적인 향과 맛을 가열과 숙성으로 제거하여 섭취가 용이하도록 흑마늘이 개발되었다.

흑마늘은 특수한 조건에서 발효, 숙성시켜 기능성을 강화한 검은색의 마늘이다. 그러나 새롭게 개발된 흑마늘의 효능에 대한 생리학적 기전에 대한 연구가 미비하여, 본 연구에서는 흑마늘이 항산화 효과뿐만 아니라 암 전이에 관련된 matrix metalloproteinases 효소의 활성 및 발현에 대한 억제 효과가 
있다는 것을 발견하여 그 연구 결과를 보고하고자 한다.

\section{재료 및 방법}

\section{재료 및 시료의 제조}

실험에 사용된 마늘은 뿌리 부분을 제거하고 자동 박피한 깐 마늘을 흐르는 물에 3회 세척한 다음 자연 건조하였고, 그 다음 마늘을 숙성기에서 $50 \sim 90^{\circ} \mathrm{C}$ 까지 온도를 변화시키면서 약 15 일 숙성시켜 검은색의 흑마늘을 제조하였다. 흑마늘 시 료는 진공동결건조기(EYELA FREE2E DRYER FDV-810)를 이 용하여 동결건조시킨 다음 분쇄기로 분말화시켰다. 메탄올 추 출물 제조를 위해 동결건조 시료 $100 \mathrm{~g}$ 에 메탄올 11 를 가하여 $40^{\circ} \mathrm{C}$ 에서 3 회 반복하여 추출한 다음 여과한 여액을 회전식 진공농축기를 이용하여 완전 휘발시킨 후dimethyl sulfoxide 를 이용하여 일정한 농도로 희석하여 사용하였다. 세포배양을 위한 Dulbecco's Modified Eagle's Medium (DMEM), Trypsin-EDTA, penicillin/streptomycin/amphotericin (각각 $10,000 \mathrm{U} / \mathrm{ml}, 10,000 \mu \mathrm{g} / \mathrm{ml}$ 및 2,500 $\mu \mathrm{g} / \mathrm{ml}$ ), fetal bovine serum (FBS) 시약은 Gibco BRL, Life Technologies (USA)으로부 터 구입하였다. HT1080 세포는American Type of Culture Collection (Manassas, VA, USA)로부터 구입하였다. MTT 시 약, gelatin, agarose, PMA (phorbol 12-myristate 13-acetate) 및 기타 시약은 Sigma Chemical Co. (St. Louis, MO, USA)로 부터 구입하였다.

\section{DPPH radical assay}

Brand-Williams의 실험방법을 변형하여 1,1-diphenyl-2picrylhydrazyl (DPPH) radical에 대한 ABGE의 소거능력을 측정하였다[4]. 시험농도의 $\mathrm{ABGE}$ 를 $\mathrm{DPPH}$ 용액에 가하여 10 $\mathrm{sec}$ 동안 잘 혼합한 다음 실온에서 $20 \mathrm{~min}$ 동안 반응시킨 후 $525 \mathrm{~nm}$ 에서 흡광도를 측정하였다. 양성 대조군으로 $0.1 \%$ vitamin C를 사용하였고, DPPH radical 함량은 시료 첨가군과 대조군의 흡광도 비를 \% 값으로 환산하여 나타내었다.

\section{Hydroxyl radical assay}

Chung 등의 실험방법을 변형하여 hydroxyl radical을 측정 하였다[9]. $50 \mu \mathrm{l}$ 의 $10 \mathrm{mM} \mathrm{FeSO}_{4}$ 와 $50 \mu \mathrm{l}$ 의 $10 \mathrm{mM} \mathrm{H}_{2} \mathrm{O}_{2}$ 를 이용한 Fenton반응으로 hydroxyl radical를 발생시켰다. 발생 된 radical을 $25 \mu \mathrm{l}$ 의 $10 \mathrm{mM} \mathrm{EDTA}, 25 \mu \mathrm{l}$ 의 $10 \mathrm{mM}$ 2-deoxyribose, $150 \mu \mathrm{l}$ 의 $0.1 \mathrm{M}$ phosphate buffer $(\mathrm{pH}$ 7.4)의 존재 하에 서 시험농도의 $\mathrm{ABGE}$ 와 반응시킨 다음 $37^{\circ} \mathrm{C}$ 에서 $4 \mathrm{hr}$ 동안 반응시켰다. 여기에 $250 \mu \mathrm{l}$ 의 2.8\% TCA (trichloroacetic acid) 및 $250 \mu \mathrm{l}$ 의 $1 \% \mathrm{TBA}$ (thiobabituric acid)를 첨가하여 $100^{\circ} \mathrm{C}$ 로 가열한 후 상온에서 식힌 다음 $1,000 \times \mathrm{g}$ 에서 $5 \mathrm{~min}$ 동안 원심 분리하였다. 회수한 상등액의 흡광도를 $532 \mathrm{~nm}$ 에서 측정하여 시료 첨가 전후의 흡광도 비를 \% 값으로 환산하여 항산화 활
성을 나타내었다.

\section{Hydrogen Peroxide Scavenging Assay}

Choi 등의 실험방법을 변형하여 Hydrogen peroxide에 대 한 소거활성을 측정하였다[8]. $80 \mu \mathrm{l}$ 의 ABGE, $20 \mu \mathrm{l}$ 의 $10 \mathrm{mM}$ Hydrogen peroxide 및 $100 \mu 1$ 의 $0.01 \mathrm{M}$ 인산완충용액(pH 5.0) 을 $37^{\circ} \mathrm{C}$ 에서 $5 \mathrm{~min}$ 동안 유지시킨 후에 $15 \mu \mathrm{l}$ 의 $1.25 \mathrm{mM} \mathrm{ABTS}$ 및 $30 \mu \mathrm{l}$ 의 peroxidase $37^{\circ} \mathrm{C}$ 에서 $10 \mathrm{~min}$ 동안 반응시킨 후 405 $\mathrm{nm}$ 에서 흡광도를 측정하였다. 양성 대조군으로 $0.1 \%$ vita$\min \mathrm{C}$ 를 사용하였다. 항산화 활성은 시료 첨가 전후의 흡광도 비를 \% 값으로 환산하였다.

\section{환원력 Assay}

Oyaizu의 방법에 따라 측정하였다[19]. 시료 $1 \mathrm{ml}$ 에 $\mathrm{pH} 6.6$ 의 $200 \mathrm{mM}$ 인산 완충용액 및 $1 \%$ 의 potassium ferricyanide를 각 $1 \mathrm{ml}$ 씩 차례로 가하여 교반한 후 $50^{\circ} \mathrm{C}$ 의 수욕상에서 20 $\min$ 동안 반응시켰다. 여기에 $10 \% \mathrm{TCA}$ 용액 $1 \mathrm{ml}$ 를 가하여 $13,500 \times g$ 에서 $15 \mathrm{~min}$ 동안 원심분리하여 얻은 상등액 $1 \mathrm{ml}$ 에 증류수 및 ferric chloride 각 $1 \mathrm{ml}$ 를 가하여 혼합한 후 700 $\mathrm{nm}$ 에서 흡광도를 측정하였다. 양성 대조군으로 $0.01 \%$ vita$\min C$ 를 사용하였다. 시료의 환원력은 시료 첨가군와 대조군 의 흡광도 비를 \% 값으로 환산하여 나타내었다.

\section{MTT assay}

$\mathrm{HT} 1080$ 세포는 $5 \% \mathrm{CO}_{2}$ 및 $37^{\circ} \mathrm{C}$ 에서 $95 \%$ 이상의 습도가 유지되는 배양기에서 $10 \%$ fetal bovine serum, $2 \mathrm{mM}$ glutamine, $10,000 \mathrm{U} / \mathrm{ml}$ penicillin $/ 10,000 \mu \mathrm{g} / \mathrm{ml}$ streptomycin을 포함하는 DMEM 배지에서 배양하였다.

Hansen의 방법에 따라 HT1080세포에 대한 ABGE의 세포 독성을 MTT (3-(4,5- dimethyl-2-yl)-2,5-diphenyltetrazolium bromide)방법을 이용하여 측정하였다[10].

\section{In vitro 지질과산화에 대한 항산화 활성}

$\mathrm{ABGE}$ 를 10, 50, 100 및 $500 \mu \mathrm{g} / \mathrm{ml}$ 의 농도로 linolenic acid emulsion과 혼합한 후에 $0.8 \mathrm{mM} \mathrm{H}_{2} \mathrm{O}_{2}$ 및 $0.8 \mathrm{mM} \mathrm{FeSO}_{4}$ 를 혼합한 용액을 $5 \mathrm{hr}$ 동안 반응 후 $0.4 \% \mathrm{TBA}$ 를 첨가하고 $95^{\circ} \mathrm{C}$ 에서 $2 \mathrm{hr}$ 반응시킨 다음 실온에서 $10 \mathrm{~min}$ 동안 반응시켰다. 그 다음 $15: 1$ 비율의 n-butanol : pyridine 용액을 $500 \mu \mathrm{l}$ 첨가하 고 $1,000 \times g$ 에서 $10 \mathrm{~min}$ 동안 원심분리한 후 상등액을 532 $\mathrm{nm}$ 에서 흡광도를 측정하여 지질과산화 정도는 시료 첨가 전 후의 흡광도 비를 \% 값으로 환산하여 나타내었다. 양성 대조 군으로는 $0.1 \%$ vitamin $\mathrm{E}$ 를 사용하였다.

\section{세포에서 지질과산화에 대한 항산화 활성}

6-well plate에 배양한 HT1080 세포에 ABGE를 1, 5, 10, 50 및 $100 \mu \mathrm{gg} / \mathrm{ml}$ 의 농도로 처리한 후에 $80 \mathrm{mM} \mathrm{H}_{2} \mathrm{O}_{2}$ 및 80 
$\mathrm{mM} \mathrm{FeSO}_{4}$ 를 혼합한 용액 $40 \mu \mathrm{l}$ 를 처리하여 $5 \mathrm{hr}$ 후 $\mathrm{PBS}$ 로 2번 세척하였다. Trypsin-EDTA를 처리하여 세포를 회수하여 각 well에 DMEM $500 \mu \mathrm{l}$ 를 넣어 현탁 후 새 튜브에 옮긴고 $1,000 \times g$ 에서 $5 \mathrm{~min}$ 동안 원심분리 하였다. 상등액을 버리고 $1.2 \% \mathrm{KCl}$ 을 $30 \mu \mathrm{l}$ 넣고 혼합한 후 1\% SDS $50 \mu \mathrm{l}$, acetic acid (pH 3.7) $375 \mu \mathrm{l}, 0.8 \%$ TBA $375 \mu \mathrm{l}$ 를 첨가하여 $95^{\circ} \mathrm{C}$ 에서 $2 \mathrm{hr}$ 동안 반응시킨 후 실온에서 $10 \mathrm{~min}$ 동안 반응시켰다. 그 다음 15:1 비율의 n-butanol : pyridine 용액 $500 \mu 1$ 를 첨가한 후에 $1,000 \times g$ 에서 $10 \mathrm{~min}$ 동안 원심분리한 후, 상등액을 $532 \mathrm{~nm}$ 에 서 흡광도를 측정하여 지질과산화 정도는 시료 첨가 전후의 흡광도 비를 \% 값으로 환산하였다.

\section{Hydroxyl radical에 의한 DNA 손상을 전기영동법으로 분석}

Fenton반응에 의해 발생된 hydroxyl radical에 노출된 DNA의 산화는 기존의 방법에 따라 수행하였다[17]. 먼저 100 $\mu \mathrm{l}$ 의 DNA 용액에 시험농도의 $\mathrm{ABGE}$, 최종농도가 각각 200 $\mu \mathrm{M} \mathrm{FeSO}_{4}, 1 \mathrm{mM} \mathrm{H}_{2} \mathrm{O}_{2}$ 및 $50 \mathrm{\mu g} / \mathrm{ml}$ 인 genomic DNA를 첨가 하였다. 반응 혼합물을 $30 \mathrm{~min}$ 동안 상온에서 반응시킨 후 최종농도가 $10 \mathrm{mM}$ 이 되도록 $\mathrm{EDTA}$ 를 첨가하여 반응을 종결 시켰다. DNA $1 \mu \mathrm{g}$ 을 포함하는 $20 \mu \mathrm{l}$ 의 반응 혼합물을 1\% agarose gel에서 $100 \mathrm{~V}$ 로 $30 \mathrm{~min}$ 동안 전기영동한 후 Gel은 LAS3000 ${ }^{\circledR}$ image analyzer (Fujifilm Life Science, Tokyo, Japan)를 이용하여 촬영하였다.

\section{Gelatin zymography}

MMP-2 및 MMP-9 활성은 FBS를 첨가하지 않은 DMEM 배지에서 배양한 HT1080 세포에 ABGE를 처리한 후에 기존 방법에 따라 실험을 수행하였다[5]. $50 \mathrm{\mu g}$ 의 총 단백질을 함유 하는 세포 배양액을 $1.5 \mathrm{mg} / \mathrm{ml}$ gelatin을 포함하는 비환원조 건의 $10 \%$ polyacrylamide gel을 이용하여 전기영동 하였다. Gel은 1\% Coomassie brilliant blue R250 용액으로 $1 \mathrm{hr}$ 동안 염색하고, 탈색용액 ( $30 \%$ methanol, $10 \%$ acetic acid)으로 30 $\min$ 동안 2회 탈색시켜 gel을 관찰하였다.

\section{Western blot analysis}

$\mathrm{HT} 1080$ 세포에 용출 완충용액 $(50 \mathrm{mM}$ Tris - HCl, pH 7.5, $0.4 \%$ Nonidet P-40, $120 \mathrm{mM} \mathrm{NaCl}, 1.5 \mathrm{mM} \mathrm{MgCl} 2,2 \mathrm{mM}$ phenylmethylsulfonyl fluoride, $80 \mathrm{\mu g} / \mathrm{ml}$ leupeptin, $3 \mathrm{mM}$ $\mathrm{NaF}$ 및 $1 \mathrm{mM} \mathrm{DTT}$ )을 첨가하고 $4^{\circ} \mathrm{C}$ 에서 $30 \mathrm{~min}$ 동안 처리하 였다. $10 \mu \mathrm{g}$ 의 세포 용출액을 $10 \%$ polyacrylamide gel에서 전 기영동한 후 단백질을 nitrocellulose membrane으로 전이시 켰다. 그 다음, $10 \%$ skim milk를 nitrocellulose membrane에 전처리하고 목적 단백질에 대한 1차 항체(anti-MMP-2, antiMMP-9, anti-Nrf2, anti-SOD1, anti-beta-actin 항체)를 $2 \mathrm{hr}$ 동 안 처리한 후 2차 항체를 처리하여, chemiluminescent ECL kit (Amersham Pharmacia Biotech)로 제조사의 지침에 따라 목적 단백질을 검출하였다. Western blots의 band는 LAS $3000^{\circledR}$ image analyzer (Fujifilm Life Science, Tokyo, Japan)를 이용 하여 관찰한 후 촬영하였다.

\section{통계처리}

각 실험은 3회 이상 반복 실험을 통하여 결과를 얻어 각각의 시료 농도에 대해 평균 \pm 표준편차로 나타내었다. 각 시료 농도 군에 대한 유의검정은 대조군과 비교하여 Student's $t$ test 한 후 $\mathrm{p}<0.05$ 값을 통계적으로 유의성 있는 결과로 간주하였다.

\section{결 과}

Cell free systems에서 DPPH, hydroxyl radical과 hydrogen peroxide에 대한 $\mathrm{ABGE}$ 의 항산화 효과 및 환원력

생체에서 산화적 스트레스와 관련되어 있는 $\mathrm{DPPH}$, hydroxyl radical, hydrogen peroxide와 같은 활성산소종에 대한 $\mathrm{ABGE}$ 의 소거능력 및 환원력에 대하여 조사하였다. Fig. $1 \mathrm{~A}$ 에 $\mathrm{DPPH}$ radical에 대한 $\mathrm{ABGE}$ 의 소거활성에 대한 결과를 나타 내었다. ABGE는 $50 \mathrm{\mu g} / \mathrm{ml}$ 이상에서 대조군에 비하여 유의성 있게 DPPH radical의 함량을 감소시켰다( $\mathrm{p}<0.05)$. 그러나 100 $\mu \mathrm{g} / \mathrm{ml}$ 이상에서는 $\mathrm{ABGE}$ 의 농도가 증가하더라도 DPPH radicals의 소거능력에 비례하여 증가하지는 않았다. 과산화수소 와 ferrous sulfate를 반응시키는 Fenton reaction에 의하여 발 생되는 hydroxyl radical에 대한 $\mathrm{ABGE}$ 의 소거능력에 대한 결 과는 Fig. 1B에 나타내었다. Hydroxyl radical은 $10 \mu \mathrm{g} / \mathrm{ml}$ 의 $\mathrm{ABGE}$ 의 존재 하에서 소거되었으며, $50 \mu \mathrm{g} / \mathrm{ml}$ 이상에서는 $\mathrm{ABGE}$ 의 농도가 증가함에 따라 hydroxyl radical의 소거 능력 도 유의성 있게 증가되는 것으로 나타났다. 과산화수소에 대 한 $\mathrm{ABGE}$ 의 항산화 효과도 Fig. $1 \mathrm{C}$ 에서 보여지는 바와 같이 농도에 비례하여 유의성 있게 증가하는 것으로 나타났다. 따 라서, 3 가지 활성산소종 중 $\mathrm{ABGE}$ 는 과산화수소에 대한 소거 능력이 가장 우수한 것으로 나타났으며, $\mathrm{ABGE}$ 는 $10 \mu \mathrm{g} / \mathrm{ml}$ 의 농도에서 hydroxyl radical에 대한 소거능력이 양성 대조군으 로 사용된 $0.1 \%$ vitamin C와 유사한 것으로 나타났다. 그러나 Fig. 1D에서 보는 바와 같이 $\mathrm{ABGE}$ 의 환원능력은 $1,000 \mu \mathrm{g} / \mathrm{ml}$ 이하의 농도에서 관찰되지 않았다. 이러한 결과로서 $\mathrm{ABGE}$ 의 활성산소 소거능력은 환원능력과는 직접적인 연관성이 없다 는 것을 알 수 있었다.

Hydroxyl radical에 의한 genomic DNA 산화에 대한 $\mathrm{ABGE}$ 의 항산화 효과

사람 섬유아육종세포인 HT1080포로부터 분리한 genomic DNA를 이용하여 Fenton 반응에 의하여 발생된 hydroxyl radical에 의한 DNA의 산화적 손상에 대한 $\mathrm{ABGE}$ 의 항산화 효과를 조사하였다. 본 실험에서 $\mathrm{ABGE}$ 의 존재 및 부재의 조 

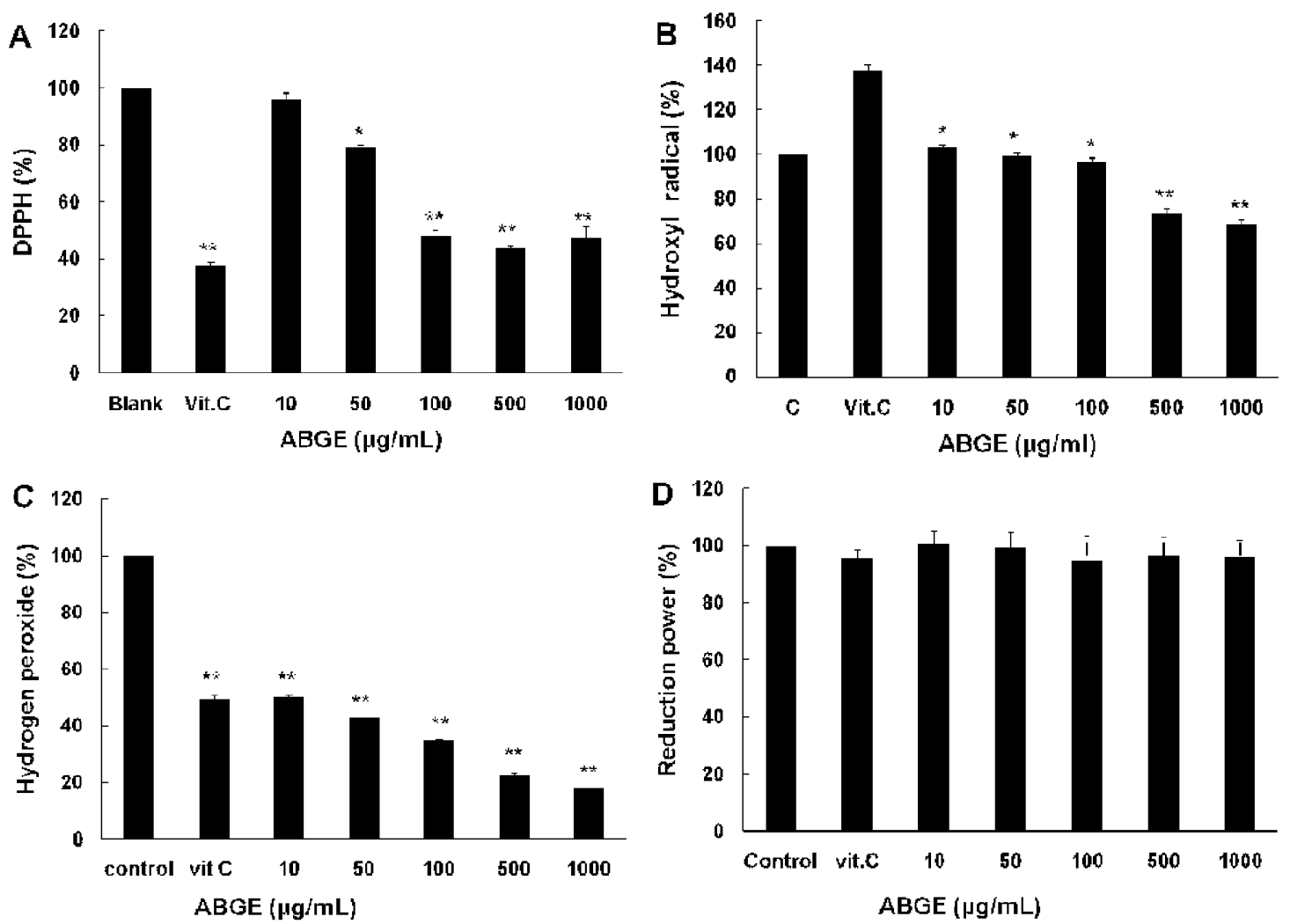

Fig. 1. Scavenging activities of ABGE on DPPH radical, hydroxyl radical, hydrogen peroxide. DPPH radical (A), hydroxyl radical by Fenton reaction (B), hydrogen peroxide $(C)$ and reducing power (D) were evaluated in the presence of ABGE. After ABGE at the indicated concentration was reacted with each radical, the optical density of each reaction mixture was measured at a specific wave length. Data are given as means of values \pm SD from three independent experiments. Level of significance was identified statistically $\left({ }^{*} p<0.05 ;{ }^{* *} p<0.01\right)$ using Student's $t$ test.

건에서 $\mathrm{DNA}$ 전기영동을 이용하여 $200 \mu \mathrm{M} \mathrm{Fe}(\mathrm{II})$ 및 $2 \mathrm{mM}$ $\mathrm{H}_{2} \mathrm{O}_{2}$ 를 사용한 Fenton반응에 의하여 발생된 hydroxyl radical 에 노출된 DNA의 산화적 손상을 조사하였다. $30 \mathrm{~min}$ 반응 후 대조군의 genomic DNA는 Fig. 2에서 보여지는 바와 같이 분해되는 것을 확인 할 수 있었다. 그러나 $\mathrm{ABGE}$ 를 첨가한

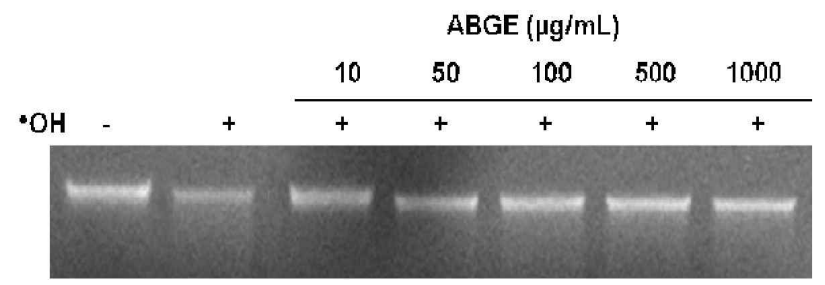

Fig. 2. Protective effect of ABGE on DNA oxidative damage induced by hydroxyl radical. Genomic DNA purified from HT1080 cells was pre-treated with ABGE for $1 \mathrm{hr}$ before exposed to $\bullet \mathrm{OH}$ using Fenton reaction. After 30 min, reaction mixture containing about $1 \mu \mathrm{g}$ of DNA was electrophorased on a $1 \%$ agarose gel for $30 \mathrm{~min}$ at 100 $\mathrm{V}$ and visualized by UV light after stained with 1 $\mathrm{mg} /$ mlethidium bromide.
군에서는 genomic DNA의 산화적 손상이 유의성 있게 억제되 었다. Hydroxyl radical에 의한 DNA의 산화적 손상은 $10 \mathrm{\mu g} /$

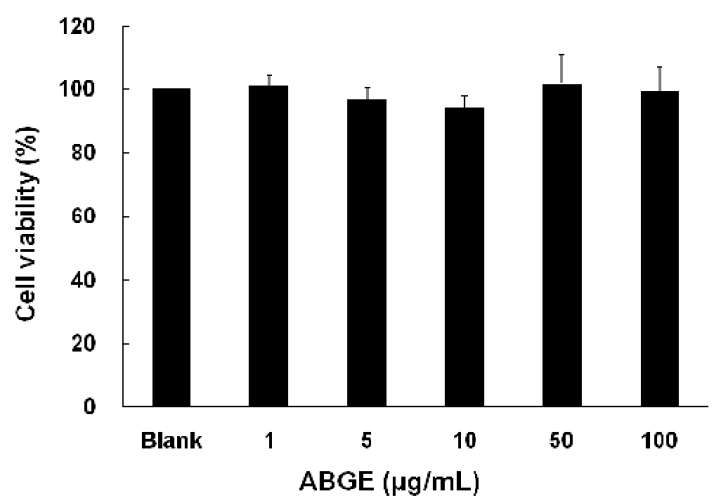

Fig. 3. Effect of ABGE on viability of human fibromasarcoma cells. HT1080 cells were treated with ABGE at 1, 5, 10, 50 and $100 \mu \mathrm{g} / \mathrm{ml}$. Cell viability was determined by MTT assay after $24 \mathrm{hr}$. Data are given as means of values \pm SD from three independent experiments. Level of significance was identified statistically $\left({ }^{*} p<0.05 ;{ }^{* *} p<0.01\right)$ using Student's $t$ test. 

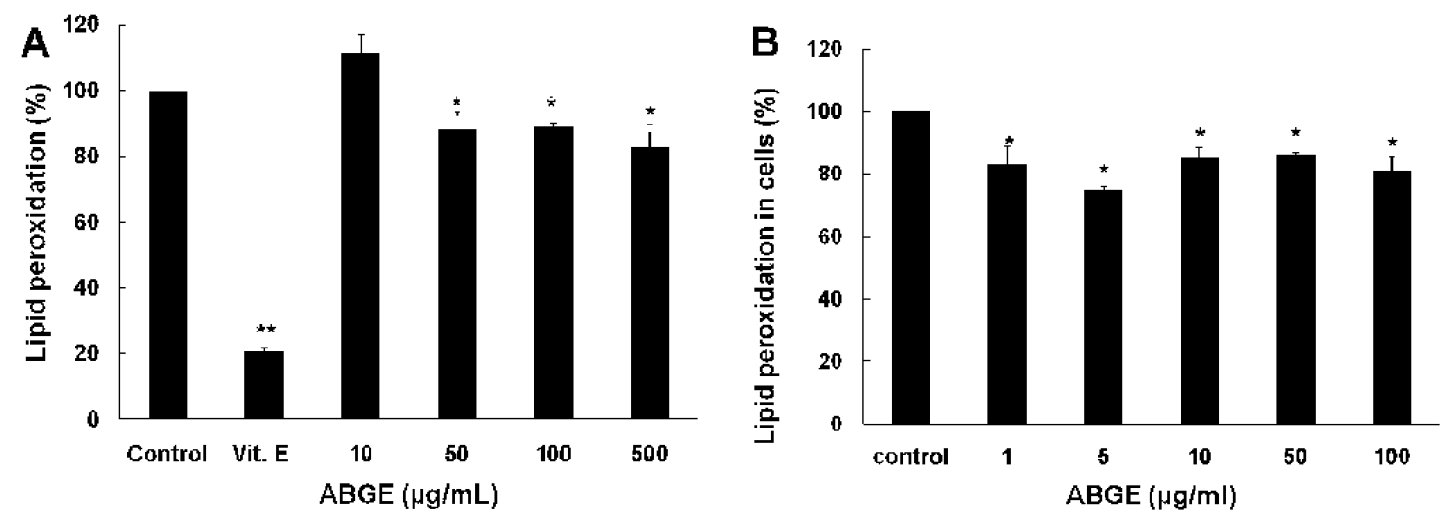

Fig. 4. Effect of $A B G E$ on lipid peroxidation in vitro To test antioxidant effect of ABGE on lipid peroxidation, linoleic acid (A) and HT1080 cells (B) treated with various concentrations of ABGE were used in this study. Data are given as means of values \pm SD from three independent experiments. Level of significance was identified statistically $\left({ }^{*} p<0.05 ;{ }^{* *} p<0.01\right)$ using Student's $t$ test.

$\mathrm{ml}$ 이상 농도의 $\mathrm{ABGE}$ 에 의하여 억제되는 것으로 나타났다.

\section{세포독성에 미치는 $\mathrm{ABGE}$ 의 영향}

본 실험에서는 $\mathrm{ABGE}$ 가 세포성장에 미치는 영향을 관찰하 기 위하여 세포 독성 유무를 조사하였다. MTT assay를 이용하 여 ABGE의 세포독성 효과를 조사하였으며, Fig. 3에서 보여지 는 바와 같이 HT1080세포에서 $100 \mu \mathrm{g} / \mathrm{ml}$ 이하의 농도에서 대 조군과 비교하여 어떠한 독성 효과도 없는 것으로 판정되었 다. 따라서, $100 \mu \mathrm{g} / \mathrm{ml}$ 이하의 농도에서 ABGE는 본 연구에서 사용된 HT 1080세포에 대하여 안전하다는 것을 나타낸다.

\section{In vitro 및 세포 수준에서 지질과산화에 대한 $\mathrm{ABGE}$ 의 항} 산화효과

In vitro에서 지질과산화에 대한 $\mathrm{ABGE}$ 에 의한 항산화 효과 를 조사하기 위하여 linolenic acid를 Fenton반응으로 발생시 킨 hydroxyl radical에 노출시켰다. 양성 대조군으로는 친유성 항산화제인 $0.1 \%$ vitamin $\mathrm{E}$ 를 사용하였다. $\mathrm{ABGE}$ 의 지질과산 화에 대한 항산화 효과를 조사한 결과, Fig. $4 \mathrm{~A}$ 에서 보는 바와 같이 $10 \mu \mathrm{g} / \mathrm{ml}$ 의 ABGE는 hydroxyl radical에 의한 linolenic acid의 과산화에 대한 억제효과가 없었으나, $50 \mu \mathrm{g} / \mathrm{ml}$ 이상의 $\mathrm{ABGE}$ 에서는 지질과산화를 억제 효과가 관찰되었다. 세포수 준에서 지질과산화에 대한 $\mathrm{ABGE}$ 의 항산화 효과를 조사한 결 과, Fig. $4 \mathrm{~B}$ 에서 보는 바와 같이 in vitro에서와는 달리 $1 \mathrm{\mu g} / \mathrm{ml}$ 이상의 농도에서 $\mathrm{ABGE}$ 는 지질과산화를 유의성 있게 억제시 켰다.

사람 섬유아육종세포에서 MMP-2 및 MMP -9에 대한 억 제효과

본 연구에서는 $\mathrm{ABGE}$ 가 $\mathrm{MMP}-2$ 및 $\mathrm{MMP}-9$ 의 활성에 대한 억제효과를 조사하기 위하여 암전이에 널리 이용되는 HT1080 세포를 이용하여 MMPs의 분비를 자극시키는 phorbol-12- myristate-13-acetate (PMA)를 ABGE 전처리 후에 $72 \mathrm{hr}$ 동안 처리한 후, 세포배양 상등액을 이용하여 gelatin zymography 를 수행하였다. Fig. 5에서 보는 바와 같이 PMA로 자극하지 않은 공시험군에 비하여 PMA로 자극한 대조군에서는 pro-MMP-2의 불활성 형태가 활성인 형태의 MMP-2로 전환 되는 것을 관찰할 수 있었으나, pro-MMP-9 band에서는 MMP-9와 결합되어 나타나 구분할 수 없었다. ABGE의 처리 군에서는 $50 \mu \mathrm{g} / \mathrm{ml}$ 이상의 농도에서 $\mathrm{MMP}-2$ 와 MMP-9의 활 성이 모두 감소되는 것을 확인할 수 있었다. 더욱이 $\mathrm{ABGE}$ 의 농도가 증가함에 따라 MMP-2와 MMP-9의 활성이 비례적으 로 억제되는 것을 알 수 있었다.

사람 섬유아육종세포에서 $\mathrm{MMP}-2$ 및 $\mathrm{MMP}-9$ 의 단백질 발현 억제효과

Gelatin zymography 실험에서 확인된 ABGE의 MMP-2 및 MMP-9의 활성에 대한 억제효과가 단백질 발현의 수준에서 조절되는 지를 연구하기 위하여 western blot을 시행하였다. Fig. 6에서 보여지는 바와 같이 PMA 처리군에서는 MMP-2와

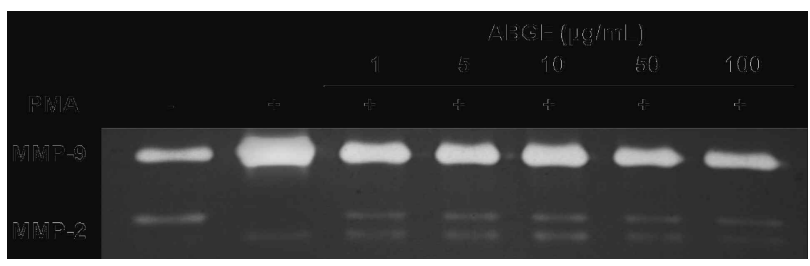

Fig. 5. Effect of ABGE on activities of MMP-2 and -9 in human fibromasarcoma cells. HT1080 cells stimulated with 1 $\mathrm{ng} / \mathrm{ml}$ of PMA to induce MMPs expression were treated with various concentrations of ABGE under serum-free conditions for $72 \mathrm{hr}$. MMP-2 and -9 activities in conditioned media were determined by gelatin zymography as described in the text. 


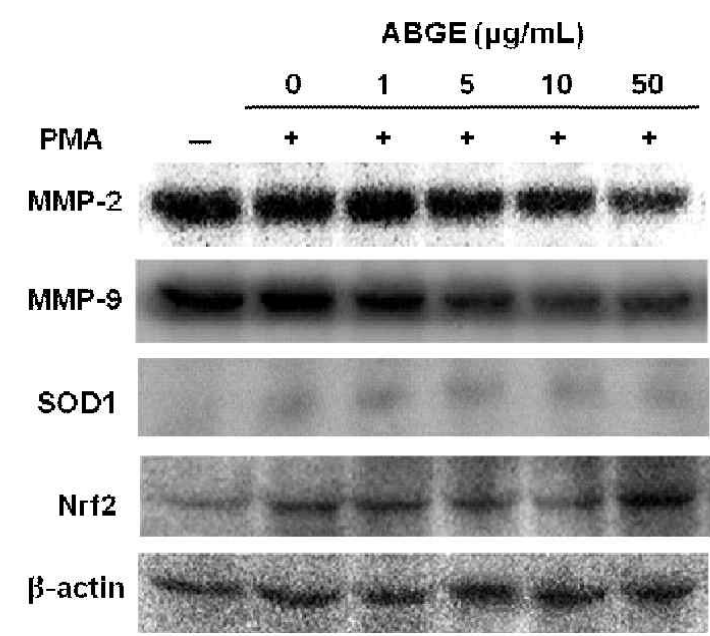

Fig. 6. Western blot analyses of protein expressions of MMP-2 and MMP-9 in in human fibromasarcoma cells. HT1080 cells were treated with various concentrations of ABGE prior to stimulation of cells with $1 \mathrm{ng} / \mathrm{ml}$ PMA. Western blot analysis of cell lysates was performed using antibodies as indicated.

MMP-9의 단백질 발현이 증가되는 것으로 나타났다. 그러나 PMA에 의하여 증가된 MMP-2와 MMP-9 단백질의 발현수준 이 $10 \mathrm{\mu g} / \mathrm{ml}$ 농도 이상의 ABGE에 의하여 뚜렷하게 억제되는 것으로 나타나, ABGE는 MMP-2 and MMP-9의 단백질 발현 을 억제시키는 것으로 판정되었다. 한편 $\mathrm{ABGE}$ 가 항산화 효소 의 발현을 조절하는데 가장 중요한 전사인자인 $\mathrm{Nrf2}$ 와 널리 알려진 항산화 효소의 하나인 SOD-1의 단백질 발현을 조사하 였다. 하지만, $\mathrm{ABGE}$ 는 $50 \mu \mathrm{g} / \mathrm{ml}$ 이하의 농도에서는 $\mathrm{Nrf2}$ 와 $\mathrm{SOD} 1$ 의 레벨을 증가시키지 않았으므로, 기대와는 달리 $\mathrm{ABGE}$ 는 직접적으로 활성산소를 억제하나 항산화 효소계의 발현에는 영향을 주지 않는 것으로 나타났다.

\section{고 찰}

Hydrogen peroxide, hydroxyl radical 및 superoxide anion 과 같은 산화적 스트레스는 여러가지 대사질병과 세포사멸에 도 중요한 역할을 한다고 알려져 있다. 세포가 활성산소에 노 출되었을 때 superoxide dismutases, catalases 및 glutathionine peroxidase와 같은 항산화 효소가 생성되어, 세포 내 산화 스트레스가 제거된다. 그러나 활성산소의 발생과 항산화 효소의 생성 사이에 균형이 깨지면 염증, 암발생 및 노화가 가속화된다는 연구가 보고 되어있다[14,15]. 따라서 산화적 스 트레스와 관련된 여러 가지 질환을 예방하기 위하여 활성산소 의 발생을 감소 시키기 위한 천연 생리활성 물질을 개발하는 것은 상당히 중요한 연구분야이다. 본 연구에서는 이러한 천 연 항산화제를 개발하는 과정에서 최근에 개발된 $\mathrm{ABGE}$ 가 활 성산소의 소거작용이 높아 살아 있는 세포에서 산화적 손상을
감소시키는데 우수한 효능이 있다는 것을 발견하였다. 먼저 DPPH radical, hydroxyl radical 및 과산화수소에 대한 ABGE 의 직접적인 소거능력을 조사하였다. 여러 가지 활성산소종 중에서 $\mathrm{ABGE}$ 는 과산화수소에 대한 소거능력이 가장 우수하 였다. 기존의 연구에서도 마늘에는 thiosulfinate와 같은 황화 합물이 과량으로 함유되어 있어 항균, 항산화 및 항염증 효과 가 우수하다는 연구보고가 있다[27]. 뿐만 아니라 ABGE에는 폴리페놀류의 화합물이 함유되어 있어 우수한 항산화 작용을 설명할 수 있다[20]. 이러한 항산화 효과 뿐만 아니라 사람 섬 유아육종 세포에서 분리한 genomic DNA를 Fenton반응에 의 하여 생성된 hydroxyl radical에 노출시킨 산화에 대하여 보호 하는 효능을 보여주었다. 세포독성 연구에서 ABGE는 사람 섬유아육종세포에서 독성작용이 없는 것으로 나타났으며, 이 것은 마늘이 오랜 기간 동안 전통적으로 안전한 식품 소재뿐 만 아니라 발열, 두통 및 인후통에 민간요법으로 널리 이용되 어 왔다는 사실로 안전성이 확보되어 왔다. 그러므로 $\mathrm{ABGE}$ 는 항산화와 관련 있는 고혈압 및 항혈전 등과 같은 혈액순환계 질환의 예방을 위하여 기능성 식품으로 개발될 수 있다. 최근 에는 마늘이 암예방에 효과가 있다는 연구 보고는 있으나[24] 그 작용기전은 아직까지 불명확하다. 따라서 본 연구에서는 암전이 과정에서 중요한 역할을 한다고 알려진 matrix metalloproteinses (MMPs)의 활성과 발현에 대한 $\mathrm{ABGE}$ 의 효능을 사람 섬유아육종세포를 이용하여 조사하였다. MMP-2와 MMP-9은 여러 가지 세포활성의 조절에 관여한다고 알려져 있는데 주로 암 침윤 및 암 전이와 연관된 세포기저막에 있는 collagen IV를 포함한 세포 외 기질성분을 가수분해하는 효소 로 알려져 있다[2]. 본 연구에서 사람 섬유아육종세 포에서 분 비되는 MMP-2 및 MMP-9의 활성에 대한 ABGE의 효능을 조 사하기 위하여 gelatin zymography를 수행하였다. 시험결과 ABGE는 MMP-2 및 MMP-9 두 가지 효소활성에 대하여 억제 효과가 있는 것으로 나타났다. 이러한 본 연구에서 발견된 효 능의 결과로 흑마늘이 하나의 암전이 작용기전을 억제할 수 있음을 알게 되었다. 또한, ABGE가 MMP-2 및 MMP-9 두 가 지 효소활성 억제 효과뿐만 아니라 western blot 분석 결과에 서 PMA로 자극된 MMPs 단백질의 발현을 억제하는 효능을 보여 주었다. 그러므로 $\mathrm{ABGE}$ 의 이러한 작용기전이 마늘의 암억제에 대한 효능을 설명할 수 있는 근거가 될 수 있다. 이러 한 연구 결과를 바탕으로 $\mathrm{ABGE}$ 는 암전이와 관련 있는 MMP-2 및 MMP-9의 활성과 발현을 억제하여 암억제에 도움 을 줄 수 있는 하나의 우수한 생리활성 소재로서 이용될 수 있으리라 기대된다.

\section{감사의 글}

이 연구는 지식경제부·부산광역시 지원 지역혁신센터사 업(RIC) 동의대학교 블루바이오 소재 개발 및 실용화 지원 센 
터의 지원으로 이루어 졌습니다.

\section{References}

1. Agarwal, K. 1996. Therapeutic actions of garlic constituents. Medicinal Research Reviews 16, 111-124.

2. Ara, T. and Y. DeClerck. 2006. Mechanisms of invasion and metastasis in human neuroblastoma. Cancer and Metastasis Reviews 25, 645-657.

3. Aronne, L., D. Nelinson, and J. Lillo. 2009. Obesity as a disease state: A new paradigm for diagnosis and treatment. Clinical Cornerstone 9, 9-29.

4. Brand-Williams, W., M. Cuvelier, and C. Berset. 1995. Use of a free radical method to evaluate antioxidant activity. LWT-Food Science and Technology 28, 25-30.

5. Chen, P., Y. Hsieh, H. Chiou, and S. Chu. 2005. Silibinin inhibits cell invasion through inactivation of both PI3K-Akt and MAPK signaling pathways. Chemico-biological interactions 156, 141-150.

6. Cheng, A., C. H. Hsu, J. K. Lin, M. M. Hsu, Y. F. Ho, T. S. Shen, J. Y. Ko, J. T. Lin, B. R. Lin, W. Ming-Shiang, H. S. Yu, S. H. Jee, G. S. Chen, T. M. Chen, C. A. Chen, M. K. Lai, Y. S. Pu, M. H. Pan, Y. J. Wang, C. C. Tsai, and C. Y. Hsieh. 2001. Phase I clinical trial of curcumin, a chemopreventive agent, in patients with high-risk or pre-malignant lesions. Anticancer Research 21, 2895-2900.

7. Cho, S., E. Bae, C. Lee, C. You, and J. Lee. 2003. A case of irritant contact dermatitis due to garlic. Korean Journal of Dermatology 41, 385-387.

8. Choi, C., S. Kim, S. Hwang, B. Choi, H. Ahn, M.Lee, S. Park, and S. Kim. 2002. Antioxidant activity and free radical scavenging capacity between Korean medicinal plants and flavonoids by assay-guided comparison. Plant science (Limerick) 163, 1161-1168.

9. Chung, S., T. Osawa, and S. Kawakishi. 1997. Hydroxyl radical-scavenging effects of spices and scavengers from brown mustard (Brassica nigra). Bioscience, biotechnology, and biochemistry 61, 118-123.

10. Hansen, M., S. Nielsen, and K. Berg. 1989. Re-examination and further development of a precise and rapid dye method for measuring cell growth/cell kill. Journal of Immunol Methods 119, 203-210.

11. Hasani-Ranjbar, S., B. Larijani, and M. Abdollahi.2009. A systematic review of the potential herbal sources of future drugs effective in oxidant-related diseases. Inflammation and Allergy 8, 2-10.

12. Imai, J., N. Ide, S. Nagae, T. Moriguchi, H. Matsuura, and Y. Itakura. 1994. Antioxidant and radical scavenging effects of aged garlic extract and its constituents. Planta Medica 60, 417.

13. Jang, M. L. Cai, G. O. Udeani, K. V. Slowing, C. F. Thomas, C. W. Beecher, H. H. Fong, N. R. Farnsworth, A. D. Kinghorn, R. G. Mehta, R. C. Moon, J. M. Pezzuto. 1997. Cancer chemopreventive activity of resveratrol, a natural product derived from grapes. Science 275, 218-220.
14. Lightfoot, T, C. F. Skibola, A. G. Smith, M. S. Forrest, P. J. Adamson, G. J. Morgan, P. M. Bracci, E. Roman, M. T. Smith, and E. A. Holly. 2006. Polymorphisms in the oxidative stress genes, superoxide dismutase, glutathione peroxidase and catalase and risk of non-Hodgkin's lymphoma. Haematologica 91, 1222-1227.

15. Looi, M., A. Z. Mohd Dali, S. A. Md Ali, W. Z. Wan Ngah, and Y. A. Mohd Yusof. 2008. Oxidative damage and antioxidant status in patients with cervical intraepithelial neoplasia and carcinoma of the cervix. European Journal of Cancer Prevention 17, 555-560.

16. Medi - ari , M., V. Rastija, M. Boji, and Male. 2009. From functional food to medicinal product: Systematic approach in analysis of polyphenolics from propolis and wine. Nutrition Journal 8, 33.

17. Milne, L, P. Nicotera, S. Orrenius, and M., B. 1993. Effects of glutathione andchelating agents on copper-mediated DNA oxidation: pro-oxidant and antioxidant properties of glutathione. Archives of Biochemistry and Biophysics 304, 102-109.

18. Ohnishi, N. and T. Yokoyama. 2004. Interactions between medicines and functional foods or dietary supplements. The Keio Journal of Medicine 53, 137-150.

19. Oyaizu, M. 1986. Studies on products of browning reaction:antioxidative activities of products of browning reaction prepared from glucosamine. JaponesseJournal of Nutrition 44, 307-305.

20. Queiroz, Y., E. Ishimoto, D. Bastos, G. Sampaio, and E. Torres. 2009. Garlic (Allium sativum L.) and ready-to-eat garlic products: In vitro antioxidant activity. Source. Food Chemistry 115, 371-374

21. Raju, J. and R. Mehta. 2009. Cancer chemopreventive and therapeutic effects of diosgenin, a food saponin. Nutrition and Cancer 61, 27-35.

22. Reddy, A. and B. Lokesh. 1994. Studies on the inhibitory effects of curcumin and eugenol on the formation of reactive oxygen species and the oxidation of ferrous iron. Molecular and Cellular Biochemistry 137, 1-8.

23. Rona, C. and E. Berardesca. 2008. Aging skin and food supplements: the myth and the truth. Clinics in Dermatology 26, 641-647.

24. Shukla, Y. and N. Kalra. 2007. Cancer chemoprevention with garlic and its constituents. Cancer Letters 247, 167-181.

25. Sirtori, C., C. Galli, J. Anderson, E. Sirtori, and A. Arnoldi. 2009. Functional foods for dyslipidaemia and cardiovascular risk prevention. Nutrition Research Reviews 22, 244-261.

26. Vasanthi, H., S. Mukherjee, and D. Das.2009. Potential Health Benefits of Broccoli-A Chemico-Biological Overview. Mini Reviews in Medicinal Chemistry 9, 749-759.

27. Wilson, E. and B. Demmig-Adams. 2007. Antioxidant, anti-inflammatory, and antimicrobial properties of garlic and onions. Nutrition \& Food Science 37, 178-183.

28. Yoon, G. 2006. Effect of garlic supplement and exercise on plasma lipid and antioxidant enzyme system in rats. The Korean Journal of Nutrition 39, 3-10. 
29. Yu, T., C. Wu, and S. Chen. 1989. Effects of pH adjustment and heat treatment on the stability and the formation of volatile compounds of garlic. Journal of Agricultural and Food Chemistry 37, 730-734.

초록 : In vitro에서 항산화 효능이 있는 흑마늘 추출물의 MMP-2 및 MMP-9에 대한 활성 억제효과

이수진 ${ }^{1} \cdot$ 남향 $^{1} \cdot$ 김문무 $^{1} \cdot$ 장호정 ${ }^{2} \cdot$ 박정애 $^{2} \cdot$ 김병우 ${ }^{2,3} \cdot$ 정경태, ${ }^{3,}$ *

( ${ }^{1}$ 동의대학교 화학과, ${ }^{2}$ 생명응용과학과, ${ }^{3}$ 블루바이오 소재 개발 센터, ${ }^{4}$ 임상병리학과)

지질, 단백질 및 $\mathrm{DNA}$ 의 산화적 손상이 관절염, 간염, 위염, 대장염 및 치주 질환과 같은 만성 염증뿐만 아니라 암 전이에 관련되어 있다고 알려져 있다. 이러한 질환의 발생을 예방하기 위하여 독성이 없는 천연 화합물을 개 발하는 것이 최근의 주요 연구 관심 대상이다. 산화적 스트레스와 관련 있는 DPPH radical, hydrogen peroxide, hydroxyl radical 및 과산화수소와 같은 활성산소에 대한 흑마늘(ABGE)의 소거능력이 연구되었다. 뿐만 아니라 TBARS assay를 이용하여 본 연구에서 사용된 산화방법으로 Fenton반응에 의하여 hydroxyl radical에 노출된 세 포에서 $\mathrm{ABGE}$ 의 항산화 효과도 조사되었다. $\mathrm{ABGE}$ 는 활성산소종 중에서 특히 과산화수소에 대한 항산화 효능이 우수하였고 hydroxyl radical에 노출된 genomic DNA의 산화에 대한 보호 효과도 관찰되었다. 살아있는 세포에 대한 산화적 스트레스도 ABGE의 존재 하에서 억제되었다. 뿐만 아니라, 암전이와 관련 있는 MMP-2 및 MMP-9 의 활성과 발현에 대한 $\mathrm{ABGE}$ 의 효과를 gelatin zymography 및 western blot을 이용하여 조사하였다. ABGE는 PMA로 자극한 사람 섬유아육종세포로부터 분비된 MMP-2 및 MMP-9의 활성과 발현을 동시에 억제 하였으므로 암을 억제 할 수 있는 하나의 생리활성물질로 개발 될 수 있으리라 판단된다. 